\title{
Intestinal stenosis from mesenteric injury after blunt abdominal trauma in children: case reports
}

\author{
Çocuklarda künt karın travması sonrası oluşan mezenterik yaralanmadan \\ kaynaklanan bağırsak darlığı: Olgu sunumları
}

\author{
Mustafa İMAMOĞLU, Haluk SARIHAN
}

\begin{abstract}
The incidence of mesenteric injury after blunt abdominal trauma (BAT) has increased in recent years; however, relatively little attention has been paid to instances of its sequelae, especially in childhood. We present three children who had post-traumatic intestinal stenosis (PIS). A history of BAT was obtained in all. They had abdominal pain, bilious vomiting and peritoneal signs. The time intervals, the duration from the initial trauma to the onset of symptoms, ranged from 23 to 62 days. Stenotic segments were parallel to the location of the previously recognized mesenteric hematoma $(\mathrm{MH})$, and resection with primary anastomosis was performed. Pathological examinations of specimens confirmed mucosal and mural ischemia and full-thickness fibrosis of the intestinal wall. In our opinion, large MH may pose an increasing risk of narrowing in the adjacent intestine at different time points. Therefore, if there is a large MH at laparotomy after BAT, it should be evacuated and the bleeding halted. For the differential diagnosis, typical BAT should be investigated carefully in cases presenting with intermittent colic abdominal pain and/or partial intestinal obstruction findings.
\end{abstract}

Key Words: Blunt abdominal trauma; children; mesenteric injury; intestinal stricture.
Künt karın travmasından kaynaklanan mezenterik yaralanmalar son yıllarda artış göstermesine rağmen, özellikle çocukluk yaş grubunda, oluşabilecek sekellerine yeterince dikkat verilmemiştir. Bu yazıda, künt travma sonrası bağırsak darlığı gelişen üç olgu sunuldu. Olgularda künt karın travma öyküsü vardı, karın ağrısı, safralı kusma ve akut karın bulguları da vardı. Travma ile şikayetlerin başlaması arasındaki zaman aralığı 23-62 gündü. Dar segmentler daha önceden tanımlanan mezenterik hematoma paraleldi ve rezeksiyon-anastomoz yapıldı. Patolojilerinde mukozal ve mural iskemi ile bağırsak duvarının tam kat fibrozisi görüldü. Büyük mezenterik hematomların komşu bağırsakta farklı süreler sonrasında darlık oluş̧urma riski olduğunu düşünmekteyiz. Bu nedenle, eğer künt karın travması sonrası laparotomide büyük bir mezenterik hematom varsa, bu boşaltılmalı ve kanama durdurulmalıdır. Tipik karın travması geçirmişlerde karın ağrısı ve/veya kısmi barsak tıkanıklığı bulguları oluştuğunda ayırıcı tanı dikkatli yapılmalıdır.

Anahtar Sözcükler: Künt karın travması; çocuklar; mezenter yaralanmasi; bağırsak darlığı.
The incidence of blunt mesenteric injury has increased in recent years due to high levels of blunt abdominal trauma (BAT). Alsayali et al. ${ }^{[1]}$ recently reported that out of 1.553 consecutive patients with BAT, 278 were admitted to their department for treatment of blunt mesenteric injury. Their operative findings showed that the small or large bowel mesentery was injured in $54 \%(n=120)$ and $9 \%(n=19)$ of patients, respectively. However, relatively little attention has been paid to instances of its sequelae, especially in childhood. One reported late sequela following BAT is post-traumatic intestinal stenosis (PIS). When seatbelt injuries are excluded, only a few pediatric PIS cases have been reported in the literature. ${ }^{[2-4]}$ Our three children with BAT-associated PIS were examined retrospectively in order to produce new suggestions for both the mechanism involved in PIS and mesenteric hematoma (MH) treatment strategies in such cases. 


\section{CASE REPORTS}

Case 1- A five-year-old boy was admitted to our clinic as a victim of physical abuse. He had bilious vomiting with abdominal pain. Abdominal examination revealed severe abdominal distension and tenderness. Blood pressure was less than $50 \mathrm{mmHg}$ and hemoglobin $(\mathrm{Hb})$ was $5.9 \mathrm{~g} / \mathrm{dl}$. Appropriate fluid resuscitation and blood transfusion were started. A Foley catheter was inserted in the bladder and gross hematuria was noted. Plain film of the abdomen demonstrated severe free intraperitoneal air, and immediate surgical exploration was performed. At laparotomy, a large gastric perforation located along the greater curvature and a splenic laceration were noted. Furthermore, large mesenteric and retroperitoneal hematomas were present, but there was no localized serosal injury or ischemic change in the wall of the adjacent intestine. Primary repair of the stomach and splenorrhaphy were performed. Oral feeding was started and was well tolerated seven days after surgery. Twenty-three days later, a colic-type abdominal pain associated with bile-stained vomiting developed. Physical examination revealed diffuse tenderness in the upper abdomen, but no fever or palpable mass was present. At this time, $\mathrm{Hb}$ level was $9.7 \mathrm{~g} / \mathrm{dl}$ and white blood cell (WBC) count $15.000 / \mathrm{mm}^{3}$. Abdominal radiographs showed a partial small bowel obstruction. Nasogastric suction, antibiotics, and parenteral nutrition were initiated for postoperative adhesions, and he was observed carefully. After two days with no apparent clinical or laboratory improvement, surgery was considered. At laparotomy, an excessive fibrosis with disruption in the location of the previously recognized distal jejunal $\mathrm{MH}$ and a thick-walled stenosis $(10 \mathrm{~cm})$ in the adjacent intestine with proximal dilatation were encountered. There were no obstructive adhesions. The stenotic segment was resected and an anastomosis performed. Histopathological examination revealed mucosal and submucosal ischemia and full-thickness fibrosis. The patient had an uneventful postoperative course.

Case 2-A 13-year-old boy was referred to our unit with anorexia, nausea, intermittent bilious vomiting, and subsequent weight loss over the previous three weeks. The day before, he had severe abdominal pain and vomited feculent material, and passed no flatus. He had been kicked in the right side of the abdomen by a friend while playing football 62 days before. For two days after the trauma, he had a low-grade abdominal pain and vomiting, but then felt well again. Abdominal examination revealed a mass in the right quadrant with peritoneal signs. Laboratory examination showed a Hb level of $10.5 \mathrm{~g} / \mathrm{dl}$ and WBC count of $19.500 / \mathrm{mm}^{3}$, with normal amylase and urinalysis results. Abdominal X-ray films showed air-fluid levels in the small intestine. An emergency laparotomy was performed and a resolved ileal $\mathrm{MH}$ with excessive fibrosis and disruption were observed. A stenotic ileal segment $(10 \mathrm{~cm})$ parallel to that location was diagnosed, and resection-anastomosis was performed. Pathological findings confirmed a severe full-thickness fibrosis of the intestinal wall.

Case 3- A five-year-old girl was referred to our unit after sustaining a major lower abdomen injury due to a collapsing heating radiator. Examination revealed tenderness and distension of the lower abdomen. Vaginal bleeding was also noted due to a large anterior vaginal laceration. A skeletal survey demonstrated a disruption of the right sacroiliac joint and pubic diastasis. Systolic blood pressure was $50 \mathrm{mmHg}$. Laboratory examination revealed a $\mathrm{Hb}$ level of $6.5 \mathrm{~g} /$ dl. Despite massive fluid replacement, shock findings continued. Seven hours following injury, an emergency laparotomy was performed. Abdominal exploration demonstrated a large diameter $\mathrm{MH}$ in the ileum. There were no mesenteric defects, localized intestinal injury or ischemic changes in the adjacent intestine. Pelvic exploration revealed an anterior bladder laceration extending through the bladder neck and $2 \mathrm{~cm}$ into the proximal urethra. Bladder, bladder neck and proximal urethral injuries were repaired, and vaginal reconstruction was performed subsequently. By the ninth postoperative day, oral feeding was started and well tolerated. Two weeks later, abdominal pain, mild distension and vomiting developed. Abdominal radiographs demonstrated a partial intestinal obstruction. A PIS was initially suspected because of our experiences with the previous cases, and surgical intervention was decided. At laparotomy, there were excessive fibrosis and disruption in the location of the previously recognized ileal $\mathrm{MH}$ and a tight fibrotic stricture $(5 \mathrm{~cm})$ in the adjacent ileum. No adhesions were determined. Resection-anastomosis was performed. Pathological examination revealed full-thickness intestinal fibrosis. She was discharged on the sixth postoperative day.

\section{DISCUSSION}

The exact cause of PIS due to MH after BAT is still in question. However, three mechanisms may be involved in its development: (1) direct disruption or occlusion of large arteries, (2) partial arterial obstruction due to compression due to a mass effect of a large $\mathrm{MH}$, and (3) disruption or occlusion of large arteries secondary to resolved MH with excessive fibrosis. ${ }^{[4-6]}$ In two of our patients, large hematomas were noted during the initial laparotomy in the mesentery without macroscopically adjacent bowel wall injury or localized ischemic changes. At their second laparotomies, an excessive fibrosis and disruption in the location of the previously recognized $\mathrm{MH}$ were present. Stenotic segments were parallel to these locations. Therefore, we postulated that resolution begins after the acute large volume of blood extravasations into the mesen- 
tery. During this period, fibroblast reorganization of the scar collagen leads to wound volume reduction and contraction. Contracture and tissue distortion may cause compression of some mesenteric arterial branches, leading to a partial obstruction. Latent poor blood perfusion may thus result in full-thickness ischemia and fibrosis of this bowel wall at different time points. In agreement with these results, pathological examinations of resected specimens from our subjects confirmed mucosal and mural ischemia and full-thickness fibrosis of the intestinal wall. Although both small and large intestinal stenoses have been reported, stenosis developed in the small intestine in all our cases. ${ }^{[7]}$ In addition, our patients had a single stenotic segment, although multiple stenotic segments have also been reported. ${ }^{[5]}$

Delayed presentations of mesenteric injuries following traffic accidents and attributed to seatbelt use have been documented in children. However, other causes of BAT may also lead to PIS through similar mechanisms. A specific history of bicycle handlebar injury, child abuse or a direct blow to the abdomen should heighten suspicion of mesentery injury. ${ }^{[5]}$ A history of similar BAT was elicited in all our cases.

In such cases, the reported time range between BAT and the onset of PIS symptoms ranges from 10 days to 26 years. The interval ranged from 23 to 62 days in our patients. Because of the tendency for late presentations, preoperative diagnosis of PIS is frequently difficult. ${ }^{[5,8]}$ Furthermore, the clinical manifestations and radiographic features of PIS are mimicked by various intestinal diseases, and are characterized by obstructive symptoms. Few adult cases have been reported in the literature, these being diagnosed preoperatively with small or large bowel barium investigation. ${ }^{[9,10]}$ In children, however, contrast studies are of limited value since the lesion is usually limited to the small bowel. Therefore, investigation of the type of injury is the first step in the preoperative diagnosis of PIS. Any child who suffers a possible BAT, including bicycle handlebar injury, child abuse or a direct blow to the anterior abdomen, and in whom abdominal pain, bilious vomiting and/or peritoneal signs develop even months or years later, may be suspected of having PIS. In appropriate cases, preoperative diagnosis may be performed using contrast intestinal passage computed tomography.

It is unclear what percentage of MH results in PIS. In our experience, however, intraoperative manage- ment of $\mathrm{MH}$ found at laparotomy depends on whether the hematoma is small or large. Small MH can be treated conservatively without late sequelae. However, in our opinion, large $\mathrm{MH}$ may pose an increasing risk of narrowing in the adjacent intestine at different time points. Therefore, if there is a large $\mathrm{MH}$ at laparotomy after BAT, it should be evacuated and the bleeding halted. In this way, we predict that less scar collagen will be deposited, and excessive mesenteric fibrosis can be prevented. Consequently, the patient is now probably not at risk for PIS. On the other hand, because of the high frequency of BAT in childhood, a history of unrecognized, typical BAT should be carefully investigated in cases presenting with intermittent colic abdominal pain and/or partial intestinal obstruction findings. If present, PIS should be considered and investigated. Primary treatment is partial resection of the stenotic segment and then anastomosis, as performed in our cases.

Conflict-of-interest issues regarding the authorship or article: None declared.

\section{REFERENCES}

1. Alsayali MM, Atkin C, Winnett J, Rahim R, Niggemeyer LE, Kossmann T. Management of blunt bowel and mesenteric injuries: experience at the Alfred Hospital. Eur J Trauma Emerg Surg 2009;35:482-8.

2. Chi T, Shin SL. Delayed intestinal stenosis after blunt abdominal trauma: report of a case. Kaohsiung J Med Sci 1998;14:734-7.

3. Shah P, Applegate KE, Buonomo C. Stricture of the duodenum and jejunum in an abused child. Pediatr Radiol 1997;27:281-3.

4. Jones VS, Soundappan SV, Cohen RC, Pitkin J, La Hei ER, Martin HC, et al. Posttraumatic small bowel obstruction in children. J Pediatr Surg 2007;42:1386-8.

5. Lynch JM, Albanese CT, Meza MP, Wiener ES. Intestinal stricture following seat belt injury in children. J Pediatr Surg 1996;31:1354-7.

6. Bryner UM, Longerbeam JK, Reeves CD. Posttraumatic ischemic stenosis of the small bowel. Arch Surg 1980;115:103941.

7. Balupuri S, Stock SE. Post traumatic large bowel stricture. Injury 1999;30:68-9.

8. Vanderschot PM, Broos PL, Gruwez JA. Stenosis of the small bowel after blunt abdominal trauma. Unfallchirurg 1992;95:71-3.

9. Lee-Elliott C, Landells W, Keane A. Using CT to reveal traumatic ischemic stricture of the terminal ileum. AJR Am J Roentgenol 2002;178:403-4.

10. De Backer AI, De Schepper AM, Vaneerdeweg W, Pelckmans P. Intestinal stenosis from mesenteric injury after blunt abdominal trauma. Eur Radiol 1999;9:1429-31. 